\title{
4. 外傷患者にお忛万視束管提影用㭪助具O陚作
}

Development of Supporting Apparatues for Injuries of Optic Canal

$$
\begin{aligned}
& \text { 大阪府三島救命救急センター ○山本浩司渡部敬次 } \\
& \text { 放射線科森原宗憲西本武司 } \\
& \text { (Morihara Munenori) (Nishimoto Takeshi) } \\
& \text { 概芳則 }
\end{aligned}
$$

（目的）当センターでは、外傷患者の頭部単純撮影はストレッチャー上にて仰臥位で行なわなければ ならず、特に視束管撮影においてはポジショニングが困難である。そこで我々は迅速かつ容易に撮影 を行なうため、視束管撮影用補助具を試作した。

（方法）従来行なっていた仰臥位での視束管の撮影方法 をF i g. 1に示す。まず舆棘耳孔線を垂直にして、a の方法では、頭部矢状面を 35 度回旋させ X線束を検側 の視束管に垂直に入射して撮影を行なう。頭部を動かす ことができない場合には、bの方法により、X線管球で 頭部矢状面に対して、35度の角度を付けて撮影を行な う。bの方法における撮影の場合、カセッテ交換の祭の 頭部移動による患者負担や再現性、X線束の斜入による 歪みの問題があるため、視束管撮影用の補助具を試作し た。補助具を使用した撮影方法を F i g. 2 に示す。X 線 C T用のヘッドホルダーを利用し、フレキシブルカセッ テをへッドホルダーの内側にセットして、その上に頭部 の固定を行う。頭部が後方に傾くような形状のホルダー を使用することにより、筷栜耳孔線が垂直になる。この 状態で、X線管球を頭部矢状面に対して 35 度の角度を 付けて撮影を行なう。反対側視束管の撮影を行なう場合 は、カセッテ交換は行なわず、X線管球を反対側に移動 する。この方法により、同一フィルム上に両側視束管を 撮影したX線写真を P h o t o. 1に示す。

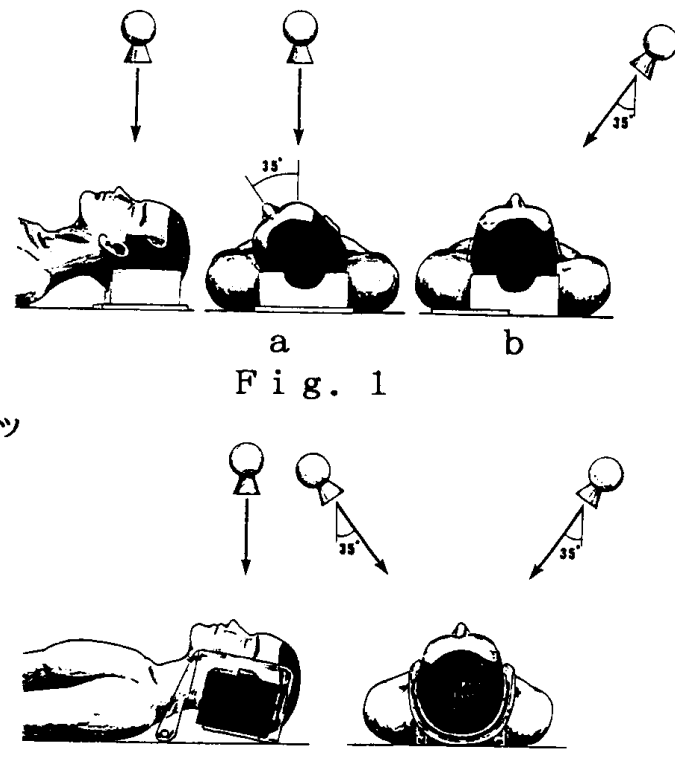

F i g. 2

（結果）ヘッドホルダーとフレキシブルカセッテを使用 することにより

1. 重偒患者においても迅速かつ容易に視束管撮影が可 能となり㛟査時間の短縮ができた。

2.X線管球の移動だけで同一フィルム上に両側の視束 管が撮影可能になり患者負担の低減ができた。

3.フレキシブルカセッテを使用することによりX線束 のフィルムに対する斜入を低隇でき充分に診断可能な画 像を得ることができた。
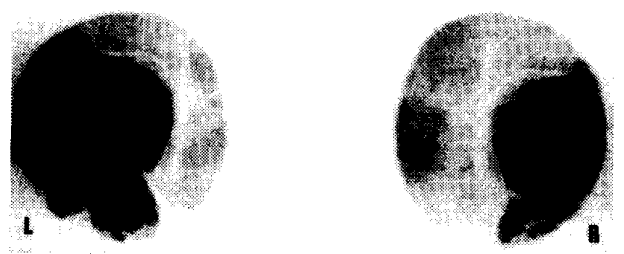

P hot o. 1

（まとめ）救命救急施設において重伤患者に対するX線撮影を行なう場合には、さまさまな問題が生 じるため技術的に非常に困難な場合があるが、今後さらに救急医療におけるX線撮影の方法について 桱討を重ねていきたいと考えている。 